University of Nebraska - Lincoln

DigitalCommons@University of Nebraska - Lincoln

Papers in Natural Resources

Natural Resources, School of

2019

Tree-ring stable isotopes show different ecophysiological strategies in native and invasive woody species of a semi-arid riparian ecosystem in the Great Plains of the United States

Tala Awada

University of Nebraska-Lincoln, tawada2@unl.edu

Kristen Skolaut

Li-Cor Biosciences

Giovanna Battipaglia

University of Campania

Matthias Saurer

WSL Swiss Federal Research Institute

Diego A. Riveros-Iregui

University of North Carolina - Chapel Hill

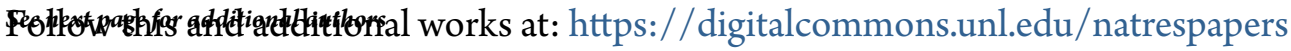

Part of the Natural Resources and Conservation Commons, Natural Resources Management and Policy Commons, and the Other Environmental Sciences Commons

Awada, Tala; Skolaut, Kristen; Battipaglia, Giovanna; Saurer, Matthias; Riveros-Iregui, Diego A.; Schapaugh, Adam; Huddle, Julie; Zhou, Xinhua; Martin, Derrell; and Cherubini, Paolo, "Tree-ring stable isotopes show different ecophysiological strategies in native and invasive woody species of a semi-arid riparian ecosystem in the Great Plains of the United States" (2019). Papers in Natural Resources. 878.

https://digitalcommons.unl.edu/natrespapers/878

This Article is brought to you for free and open access by the Natural Resources, School of at DigitalCommons@University of Nebraska - Lincoln. It has been accepted for inclusion in Papers in Natural Resources by an authorized administrator of DigitalCommons@University of Nebraska - Lincoln. 


\section{Authors}

Tala Awada, Kristen Skolaut, Giovanna Battipaglia, Matthias Saurer, Diego A. Riveros-Iregui, Adam Schapaugh, Julie Huddle, Xinhua Zhou, Derrell Martin, and Paolo Cherubini 


\title{
Tree-ring stable isotopes show different ecophysiological strategies in native and invasive woody species of a semiarid riparian ecosystem in the Great Plains of the United States
}

\author{
Tala Awada ${ }^{1}$ | Kristen Skolaut ${ }^{1,2}$ | Giovanna Battipaglia ${ }^{3}$ | Matthias Saurer ${ }^{4}$ | \\ Diego A. Riveros-Iregui ${ }^{5}$ | Adam Schapaugh ${ }^{1}$ | Julie Huddle ${ }^{1}$ | Xinhua Zhou ${ }^{1,6}$ | \\ Derrell Martin ${ }^{7}$ | Paolo Cherubini ${ }^{1,4}$ (D)
}

\footnotetext{
${ }^{1}$ School of Natural Resources, University of Nebraska, Lincoln, Nebraska

${ }^{2}$ Environmental Division, Li-Cor Biosciences, Lincoln, Nebraska

${ }^{3}$ Department of Environmental Biological, and Pharmaceutical Sciences and Technologies, University of Campania "L. Vanvitelli", Caserta, Italy

${ }^{4}$ Dendrosciences Laboratory, WSL Swiss Federal Research Institute, Birmensdorf, Switzerland

${ }^{5}$ Department of Geography, University of North Carolina, Chapel Hill, North Carolina

${ }^{6}$ Campbell Scientific Inc., Logan, Utah

${ }^{7}$ Department of Biological Systems Engineering, University of Nebraska, Lincoln, Nebraska

\section{Correspondence}

Paolo Cherubini, WSL Swiss Federal Research Institute, Birmensdorf $\mathrm{CH}-8903$, Switzerland. Email: paolo.cherubini@wsl.ch
}

Funding information

McIntire Stennis Forestry Research Funds (USDA); Nebraska Department of Natural Resources

\begin{abstract}
Persistent shifts in riparian vegetation associated with the invasion of introduced Elaeagnus angustifolia and native nonriparian Juniperus virginiana have been reported in the U.S. Great Plains, with significant impacts on ecosystem services. In Nebraska, these species have been expanding into the native Populus deltoides riparian forests along the Republican River. Using dendrochronological data and stable isotope ratios, we examined the annual growth and acclimation strategies of these three species to climatic and streamflow variability. We hypothesized that the ability of invasive species to grow under a wide range of environmental conditions favour vegetation shifts at the expense of native species. Streamflow was the strongest predictor for performance. When accompanied with above-average annual precipitation, streamflow resulted in peak tree-ring widths in $P$. deltoides. J. virginiana showed less sensitivity, and $E$. angustifolia showed no response. $\delta^{18} \mathrm{O}$ values did not differ among species, which indicates that all species compete for the same water source. $\delta^{13} \mathrm{C}$ ratios and WUEi were higher in J. virginiana than in P. deltoides and E. angustifolia and increased in all species over time. E. angustifolia and P. deltoides exhibit a strong stomatal control and response to relative humidity relative to J. virginiana, which showed anisohydric stomatal behaviour. Our results show that once established, J. virginiana and $E$. angustifolia thrive in the understory of $P$. deltoides using different adaptive and acclimation strategies. Based on current water flow management, which prevents highflood pulses through the riparian zone, these species will continue to establish and spread throughout the Republican River watershed.
\end{abstract}

\section{KEYWORDS}

carbon isotopes, Elaeagnus angustifolia, Juniperus virginiana, oxygen isotope, Populus deltoides, tree rings, water use efficiency, woody species encroachment

\section{1 | INTRODUCTION}

Riparian vegetation consists of plant communities present at the interface between aquatic and terrestrial upland areas at the fringes of rivers and streams (Naiman \& Décamps, 1997; Richardson et al., 2007). Historically, these plant communities have been characterized by distinctive assemblies of species reflective of fluvial processes and disturbances (e.g., flooding, alluvial deposition, and mineral soil 
exposure). They exhibit direct and indirect biological, physical, and chemical effects on, and are impacted by, the adjacent water through complex above- and below-ground interactions (Odum, 1971; Richardson et al., 2007). Riparian vegetation composition plays an important role in biodiversity, animal species mobility, streambank stabilization, erosion and sedimentation control, water yield, water quality, nutrient cycling, carbon sequestration, and climate regulation (e.g., Huddle et al., 2011; Núñez, Nahuelhual, \& Oyarzún, 2006; Rahel \& Olden, 2008; Sun et al., 2006).

In recent decades, unprecedented directional change in riparian vegetation cover associated with the invasion of herbaceous and woody species has been reported worldwide (Cleverly, Dahm, Thibault, McDonnell, \& Coonrod, 2006; Huddle et al., 2011; Richardson et al., 2007). Factors that facilitate the invasion include climate variability, changes in natural disturbance, and anthropogenically mediated management practices, particularly streamflow regulation and hydrologic alteration, land use change in riparian and upland areas, vegetation removal, grazing, and recreation (Huddle et al., 2011; Tabacchi et al., 2000). This has led to shifts in the structure, function, and composition of riparian vegetation, impacting ecosystem resilience and facilitating other invasions by opportunistic species (Richardson et al., 2007). Vegetation shifts favouring introduced and native nonriparian woody species in riparian areas can modify the hydrological cycle in ways that reduce water yields and affect the regeneration and growth of native riparian woody species in waterlimited areas like the Great Plains of North America (Heilman, McInnes, Kjelgaard, Owens, \& Schwinning, 2009; Stromberg, Tiller, \& Richter, 1996).

Several Populus species have typically dominated the riparian forests of the Great Plains (Huddle et al., 2011; Rood, Braatne, \& Hughes, 2003; Rood, Goater, Mahoney, Pearce, \& Smith, 2007). The successful establishment of Populus spp. depends on periodic flooding disturbances (Reynolds \& Cooper, 2010; Richardson et al., 2007) that deposit alluvial soil ideal for Populus seedling recruitment and establishment. Subsequent growth of this tree depends on the availability of resources and access to water. In the Great Plains of Nebraska, Eastern cottonwood (Populus deltoides L.) dominates riparian forests (Lovell, Gibson, \& Heschel, 2009). In recent decades, we have observed the spread of the non-native Russian olive (Elaeagnus angustifolia L.), which now constitutes the fourth most frequently occurring invasive species in the United States (Huddle et al., 2011). Eastern red cedar (Juniperus virginiana L.), an aggressive native upland species, has also encroached into over 7 million hectares east of 100th Meridian. This invasion has significantly changed canopy structure and species composition and has led to ecological and economic challenges (Huddle et al., 2011; Reynolds \& Cooper, 2010). J. virginiana and $E$. angustifolia can establish in the understory in the absence of flooding and are considered more drought resistant than $P$. deltoides.

Improving our understanding of how invasive species interact and respond to changes in the environment, particularly changes in climate and hydrology, can enhance management practices in riparian areas (Margolis, Meko, \& Touchan, 2011; Msanne et al., 2017; Mykleby et al., 2016; Rood et al., 2007; Tene et al., 2011). The use of tree-ring methods for ecological purposes, that is, dendroecology, provides the tools to study tree responses to localized biotic and abiotic environment. Factors such as climate, fluvial changes, management practices, species growth habit, and genetics influence the formation and growth of tree rings (Aus der Au et al., 2018; Cherubini et al., 2002). Studying the relationship between tree-ring width and climate patterns therefore helps to elucidate the tree species' sensitivity to environmental changes. Stable isotope ratios of carbon (C) and oxygen (O) in tree rings provide further information on past ecophysiological responses. Stable $\mathrm{C}$ isotopes ratios strongly reflect physiological and biochemical processes during photosynthesis, whereas $\mathrm{O}$ isotopes are influenced by changes in hydrological conditions and transpiration (McCarroll \& Loader, 2004). In riparian ecosystems, isotope ratios have been successfully applied to infer past changes and contributions of different water sources to tree growth (Singer et al., 2013).

In this study, we hypothesized that the invasive drought resistant J. virginiana and E. angustifulia possess greater ecophysiological plasticity and acclimate better to streamflow fluctuations than the native $P$. deltoides. This results in successful directional shifts in vegetation in the absence of disturbance. We used tree-ring growth patterns and stable isotope ratios $\left(\delta^{13} \mathrm{C}\right.$ and $\left.\delta^{18} \mathrm{O}\right)$ to examine the growth and water use efficiency (WUEi) of these species and assessed their responses to climate variability and streamflow fluctuations in a semiarid riparian ecosystem in Nebraska. Our findings provide important insights into the vegetation dynamics and shifts of water-limited riparian ecosystems and their implication for the resilience of riparian ecosystems.

\section{2 | MATERIALS AND METHODS}

\section{1 | Site characteristics and environmental data}

The study site is located in Bartley Forest, Red Willow County, Nebraska, United States, along the Republican River $\left(40^{\circ} 15^{\prime} \mathrm{N}\right.$, $100^{\circ} 16^{\prime} \mathrm{W}$; Figure 1). The Republican River is part of a larger watershed that extends across the states of Colorado, Nebraska, and Kansas. The Republican River basin site was selected because it experiences significant interannual variations in streamflow. The basin was hit particularly hard by the severe Dust Bowl droughts during the 1930s, which led to the creation of the Republican River Compact in 1943. The Compact regulates and oversees the apportion of specific percentages of stream water in the Republican River basin among the three states (Mykleby et al., 2016). Nebraska has faced legal difficulties in recent decades as declining streamflow in the Republican River inhibits its ability to meet its commitments to Kansas (Mykleby et al., 2016).

The Bartley Forest site is strategically located within the Middle Republican Natural Resources District, as defined by the State of Nebraska Department of Natural Resources (Figure 1). The forest overstory is dominated by the native P. deltoides (Eastern cottonwood), with understory composed of native Fraxinus pennsylvanica M. (green ash), Cornus drummondii M., and Cornus sericea L. (dogwood), native invasive 


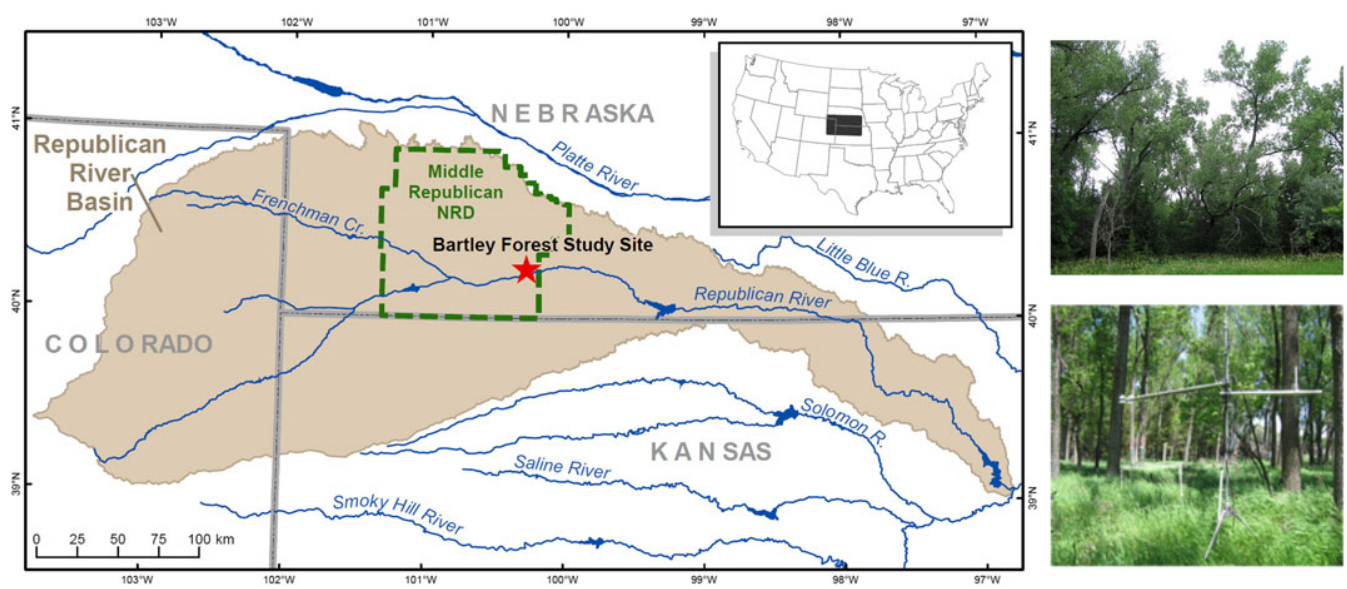

FIGURE 1 Location of research site along the Republican River in the Bartley Forest, Red Willow County, Nebraska, United States (U.S. Department of the Interior, U.S. Geological Survey)

J. virginiana (eastern redcedar), and nonnative invasive E. angustifolia (Russian olive). Site and species characteristics including tree height, density, and basal area for each species are provided in Table 1.

The climate is semiarid continental with pronounced seasonality. The growing season starts in March and lasts until October, when the first hard freeze under $0^{\circ} \mathrm{C}$ occurs. The historical long-term average annual precipitation is approximately $532 \mathrm{~mm}$, of which $75 \%$ falls during the growing season. The long-term average precipitation reported during this study was $551 \mathrm{~mm}$ (3.5\% higher than the historical record). The annual average temperature is $10.4^{\circ} \mathrm{C}$ and ranges from a minimum average low of $-10.8^{\circ} \mathrm{C}$ in January to a maximum average of $31.8^{\circ} \mathrm{C}$ in July (High Plains Regional Climate Center, HPRCC, University of Nebraska-Lincoln, http://www.hprcc.unl.edu/). Daily precipitation rates and minimum, maximum and average air temperatures for the study period were obtained from the HPRCC. Palmer Drought Index (PDI) data for the region were obtained from the National Climatic Data Center (National Oceanic and Atmospheric Association (http://www.ncdc.noaa.gov/oa/climate/research/prelim/ drought/palmer.html).

Daily streamflow data were obtained from stream gauges located upstream from Bartley Research Forest $\left(40^{\circ} 15^{\prime} \mathrm{N}, 100^{\circ} 16^{\prime} \mathrm{W}\right)$. Discharge data from a nearby stream gauge in Cambridge, Nebraska $\left(40^{\circ} 17^{\prime} 04^{\prime \prime} \mathrm{N}, 100^{\circ} 08^{\prime} 37^{\prime \prime} \mathrm{W}\right)$ were obtained from the U.S. Geological Survey Water Resources Data (http://waterdata.usgs.gov/nwis/ nwisman).

\section{2 | Tree-ring sampling}

The largest stems of $P$. deltoides, J. virginiana, and $E$. angustifolia on site were sampled between 2009 and 2010 to develop tree-ring chronologies (Table 3). Two cores from opposite sides of the tree ( $\mathrm{N}$ and $\mathrm{S}$ ) were collected with an increment borer ( $5 \mathrm{~mm}$ in diameter) at a height of $1.3 \mathrm{~m}$ or breast height (Fritts, 1966). Cores were mounted in trays and sanded to improve the visibility of the rings. Cores were then sent for analysis to the dendrochronology laboratory at the Swiss Federal Institute for Forests, Snow and Landscapes, WSL, Switzerland. Ring width was measured to the nearest $0.01 \mathrm{~mm}$, using Time Series Analysis and the Presentation (TSAP) instrument and software package (Frank Rinn, Heidelberg, Germany). Ring width of each core was cross-dated visually and statistically by Gleichläufigkeit, a statistical test of agreement in interval trends between time series and Student's $t$ test, which determines the degree of correlation between curves. Cross-dating of the trees was verified by the program COFECHA (Grissino-Mayer, Holmes, \& Fritts, 1996) and standardized using the dendrochronology software ARSTAN and a 30-year smoothing spline and a variance stabilization (Cook \& Holmes, 1986). Standardization removes biological signals in the individual samples related to age, disturbance, stand density, and size, leaving a value influenced primarily by climate. The common interval for the study was set to begin in 1973. For the final data analysis, 35 P. deltoides, $19 \mathrm{~J}$. virginiana, and 22 E. angustifolia trees were used (Table 3).

TABLE 1 Woody species composition, height, density, and basal area with standard error in the Bartley Forest, Nebraska, United States

\begin{tabular}{|c|c|c|c|c|}
\hline Species & Height (m) & Density (stems ha ${ }^{-1}$ ) & Basal area $\left(\mathrm{m}^{2} \mathrm{ha}^{-1}\right)$ & $\begin{array}{l}\text { Basal area } \\
\text { (\% of total) }\end{array}$ \\
\hline Populus deltoides & $17.8 \pm 6.7$ & $300 \pm 50$ & $8.7 \pm 0.9$ & 80.6 \\
\hline Elaeagnus angustifolia & $5.2 \pm 2.0$ & $540 \pm 160$ & $0.6 \pm 0.1$ & 5.5 \\
\hline Fraxinus pennsylvanica & $6.2 \pm 6.67$ & $140 \pm 40$ & $0.7 \pm 0.2$ & 6.5 \\
\hline Cornus spp & $3.2 \pm 2.0$ & $520 \pm 180$ & $0.04 \pm 0.01$ & 3.7 \\
\hline
\end{tabular}




\section{3 | Isotope analysis}

To determine carbon and oxygen isotopic ratios $\left(\delta^{13} \mathrm{C}\right.$ and $\delta^{18} \mathrm{O}$, respectively), the best cross-dated trees per species (i.e., those showing the highest correlation with the residual ring-width chronology) were selected (Conte et al 2018, Valor et al 2018). Early and late wood of each ring were separated in three individuals of $J$. virginiana and E. angustifolia with a scalpel under a stereomicroscope. For P. deltoides, the whole rings of four individuals were used because rings were extremely narrow. The average annual ring value for $P$. deltoides was therefore used in the statistical analysis (Table 3). Samples were milled in a centrifugal mill (ZM 1000, Retsch, Germany), and cellulose was extracted as described by Green (1963). The isotope composition of 0.9-mg cellulose was measured with elemental analysis isotope ratio mass spectrometry (IRMS-EA, Thermo, Bremen, Germany) using the element analyser Euro EA (Hekatech $\mathrm{GmbH}$ ). The standard deviation for the repeated analysis of an internal standard (commercial cellulose) was better than $0.1 \%$ o for carbon and better than $0.3 \%$ o for oxygen.

Values for $\delta^{13} \mathrm{C}$ were expressed in parts per mil (\%) relative to Vienna Pee Dee Belemnite (VPDB). The $\delta^{18} \mathrm{O}$ was determined using a continuous-flow high-temperature pyrolysis system, relative to Vienna Standard Mean Ocean Water (VSMOW) for $\delta^{18} \mathrm{O}$. Due to changes in atmospheric $\delta^{13} \mathrm{C}$, all $\delta^{13} \mathrm{C}$ values were corrected to account for changes in atmospheric $\mathrm{CO}_{2}$ since the beginning of industrialization (McCarroll \& Loader, 2004). The isotope ratios for $\delta^{13} \mathrm{C}$ and $\delta^{18} \mathrm{O}$ relative to the international standards (VPDB and VSMOW) are given in the following equations:

$$
\begin{gathered}
\delta^{13} \mathrm{C}(\% \circ)=1000\left[\frac{13 \mathrm{C} / 12 \text { Csample }}{13 \mathrm{C} / 12 \mathrm{CVPDB}}-1\right], \\
\delta^{18} \mathrm{O}(\%)=1000\left[\frac{180 / 16 \text { Osample }}{180 / 16 \text { OVSMOW }}-1\right] .
\end{gathered}
$$

Annual intrinsic WUEi values ( $\mathrm{mmol} \mathrm{mol}{ }^{-1}$ ) were calculated from the carbon isotopic composition of individual radial growth rings $\left(\delta^{13} \mathrm{C}\right.$ tree-ring) using the model described by Farquhar, O'Leary, and Berry (1982):

$$
\text { WUEi }=\frac{c a\left(b-\Delta^{13} c\right)}{1.6(b-a)}
$$

with

$$
\Delta 13 C=\frac{\left(\delta^{13} \text { Catm }-\delta^{13} \text { Ctree }- \text { ring }\right)}{\left(1+\delta^{13} \text { Ctree }- \text { ring }\right)},
$$

where $\Delta^{13} \mathrm{C}$ is the photosynthetic discrimination against ${ }^{13} \mathrm{C}$ in the atmosphere, $\delta^{13} \mathrm{Catm}$ is the carbon isotope composition of atmospheric $\mathrm{CO}_{2}, \mathrm{C}_{\mathrm{a}}$ is the mean annual atmospheric $\mathrm{CO}_{2}$ concentration (values for $c_{a}$ were obtained from NOAA, Mauna Loa station (http:// www.esrl.noaa.gov/), $a$ is the fractionation during $\mathrm{CO}_{2}$ diffusion through stomata (4.4\%o), and $\mathrm{b}$ is the fractionation during carboxylation $(27 \%$ ). It should be noted that WUEi (Equation 3) does not account for potentially low internal conductance, which might lead to an underestimation of the ci and stomatal conductance, especially in the coniferous species.

\section{4 | Statistical analysis}

The raw tree-ring widths, standardized chronology, residual chronology, and yearly basal area increment (BAI) chronology were analysed as functions of climatic factors using the DENDROCLIM2002 software package (Biondi \& Waikul, 2004). The correlations between tree-ring width and climatic variables from previous and current year (including streamflow, average monthly precipitation, average and $\mathrm{min} / \mathrm{max}$ monthly temperature, and PDSI values) were used to build mathematical models to identify the factors impacting tree-ring growth.

Additionally, linear mixed models were applied to the chronologies to evaluate how previous and current year climatic (temperature and precipitation) and hydrologic (streamflow) factors explain variation in annual growth of $P$. deltoides, J. virginiana, and $E$. angustifolia. A set of a priori models was constructed and Akaike's information criterion $\left(\mathrm{AIC}_{\mathrm{c}}\right.$ ) was adjusted for a finite sample size to rank models based on complexity and fit (not shown). Akaike (1973) established a formal relationship between Kullback-Liebler information and maximum likelihood that uses deviance as a measure of fit, adding a term to penalize more complex models (i.e., models with more parameters). Rather than relying on $p$ values, information-theoretic methods quantify the expected relative difference between competing models and a hypothetical true model (Burnham \& Anderson, 2002). The Pearson product-moment correlation coefficient $(r)$ was used to test for multicollinearity among independent variables. If $|r|<0.60$ for any pair, it was assumed multicollinearity did not compromise the model results. If multicollinearity existed for a pair of variables, only one variable was used from the set in a given model. Variance components were estimated using residual maximum likelihoods (ReML). Maximum likelihood (ML) estimates underestimate the variance components of a mixed model (Littell, Milliken, Stroup, Wolfinger, \& Schabenberger, 2006). Although ReML is the superior estimation method for mixed models, likelihoods and the likelihood-based information criterion are not comparable for fixed effects in the model. ML estimation methods were used to calculate $\mathrm{AIC}_{\mathrm{c}}$ values; ReML was then used to obtain final parameter estimates. A resulting $t$ statistic was typically declared significant at $p<0.05$.

Violation of the normality assumption was tested through inspection of quantile-quantile plots. This assumption was clearly violated using BAl growth as the response variable, thus making the model set log-transformed and refit. Two random effects were included in each model in the model set. The first was an effect due to year, which accounted for interannual variation. An effect due to tree, which accounted for the fact that two observations from the same tree will tend to be more alike than two observations from different trees, was also included. Random effects were allowed to affect the intercept in each candidate model. The R Program packages Ime4 and nlme 
(Pinheiro, Bates, DebRoy, \& Sarkar, 2009) were used for this analysis (R Development Core Team, 2009).

\section{3 | RESULTS}

\section{1 | Environmental conditions}

Mean annual cumulative precipitation and average temperatures (Figure 2) fluctuated around the long-term average reported over the study period (1973-2009) and were $551 \pm 22 \mathrm{~mm}$ and $10.6 \pm 0.13^{\circ} \mathrm{C}$, respectively. We did not observe any obvious or significant upward or downward trends. On the other hand, average annual streamflow rates fluctuated with a significant downward trend $(p<0.05)$ over the study period. There was a steep decline between 1998 and 2006 due to streamflow gauge regulation, pumping for irrigation, and drought (PDI; Figure 2). Monthly discharge rates and streamflow recorded at nearby stations increased with increasing temperatures and earlier spring snow melt. They peaked in July, lagging behind peak precipitation, which occurs in June, before declining in August (Figure 3).

\section{2 | Tree-ring growth and response to climate variability}

The two invasive species J. virginiana $\left(1,280 \pm 260\right.$ stems $\left.^{-1} \mathrm{ha}^{-1}\right)$ and E. angustifolia $\left(540 \pm 160\right.$ stems $\mathrm{ha}^{-1}$ ) constituted $65 \%$ of the total individuals on site. P. deltoides, on the other hand, had fewer but significantly larger and older individuals, representing $80 \%$ of the basal area with $300 \pm 50$ stems ha $^{-1}$ (Table 1). We did not observe any young individuals in the sapling or seedling stage for $P$. deltoides, and most understory woody species regeneration was limited to the native invasive J. virginiana. P. deltoides trees dated back to 1957; the oldest $J$. virginiana and $E$. angustifolia trees dated back to 1969. Raw tree-ring widths of the three species did not present a common trend; no significant correlations were found among the three chronologies. However, tree growth declined over time in all three species $(p<0.05)$, a trend that reversed in the 2000s (Figure 4). Data standardization to remove age-related trends, reduce variance, homogenize growth rate, and remove the impacts of abnormalities associated with disturbances eliminated any significant trends and revealed significant deviations from the mean in response to climate in 1975, 1993, and 2004 for the native P. deltoides. Invasive E. angustifolia showed slower and weaker responses with peaks in 1991-1992, 2002-2004, and 2007. The growth of J. virginiana was the least impacted by climate variability except in 2003 and 2009, when the species showed a steep decline in its standardized ring width values. $P$. deltoides' BAI increase was significantly higher compared with the other two species, as expected, and showed an overall negative trend $(p<0.05)$ between 1974 and 2002, followed by a steep and significant increase between 2003 and 2009 ( $p<0.05$ ). BAl for the invasive J. virginiana did not vary significantly between 1982 and 2002, then increased steadily until 2008 with increasing precipitation and streamflow. E. angustifolia's BAI was the least sensitive to climate variability, with a more or less constant growth rate throughout the study period (392 $\pm 24.2 \mathrm{~mm}^{2}$, Table 2).

Statistical analysis using Linear Mixed Models showed that previous and current year climatic conditions had varying impacts on raw and standardized tree-ring growth and BAI (Tables 2 and 3) depending on the species and time, that is, season or month. In general, $P$. deltoides was the most sensitive to intraannual and interannual climatic fluctuations. Streamflow was the most significant $(p<0.05)$ and important predictor for growth, especially for $P$. deltoides, whereas the two invasive species showed either positive or no response to streamflow. The peak response for $P$. deltoides and J. virginiana was recorded in 1993, a year with high precipitation and streamflow (845 mm and $6.31 \mathrm{~m}^{3} \mathrm{~s}^{-1}$, respectively). A reduction in streamflow, even in years of above-average precipitation (e.g., 1982), resulted in a decline in the growth of these two species. Growth recovery lagged a year behind an increase in streamflow. As for temperatures, our
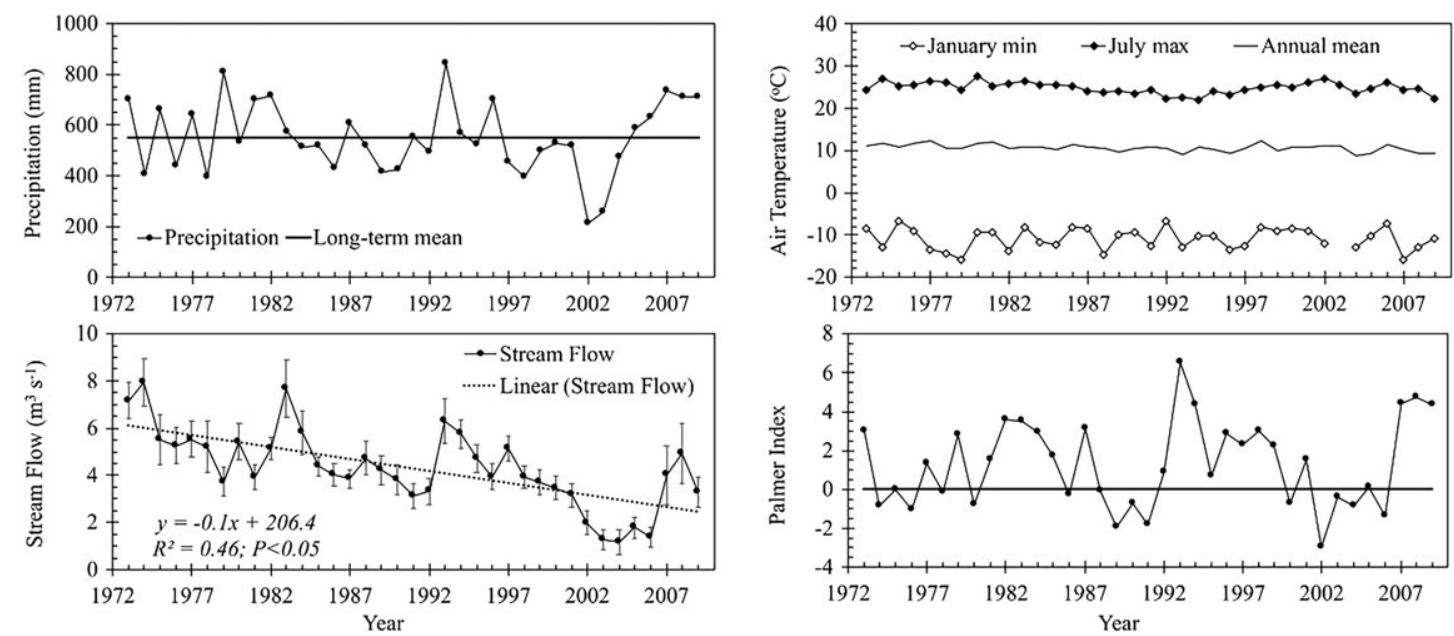

FIGURE 2 Annual precipitation; minimum, maximum and average annual air temperatures; stream flow with standard errors; and Palmer Drought Index at the study area along the Republican River, Nebraska 


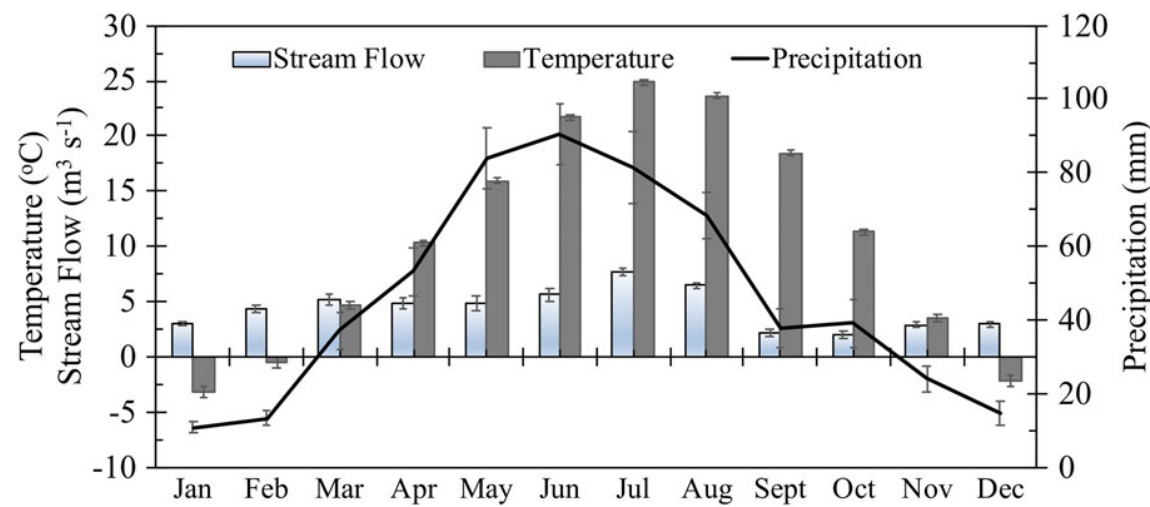

FIGURE 3 Monthly average seasonal change in temperature, streamflow, and precipitation with standard error bars for the period 1973 to 2009 in the study area along the Republican River, Nebraska
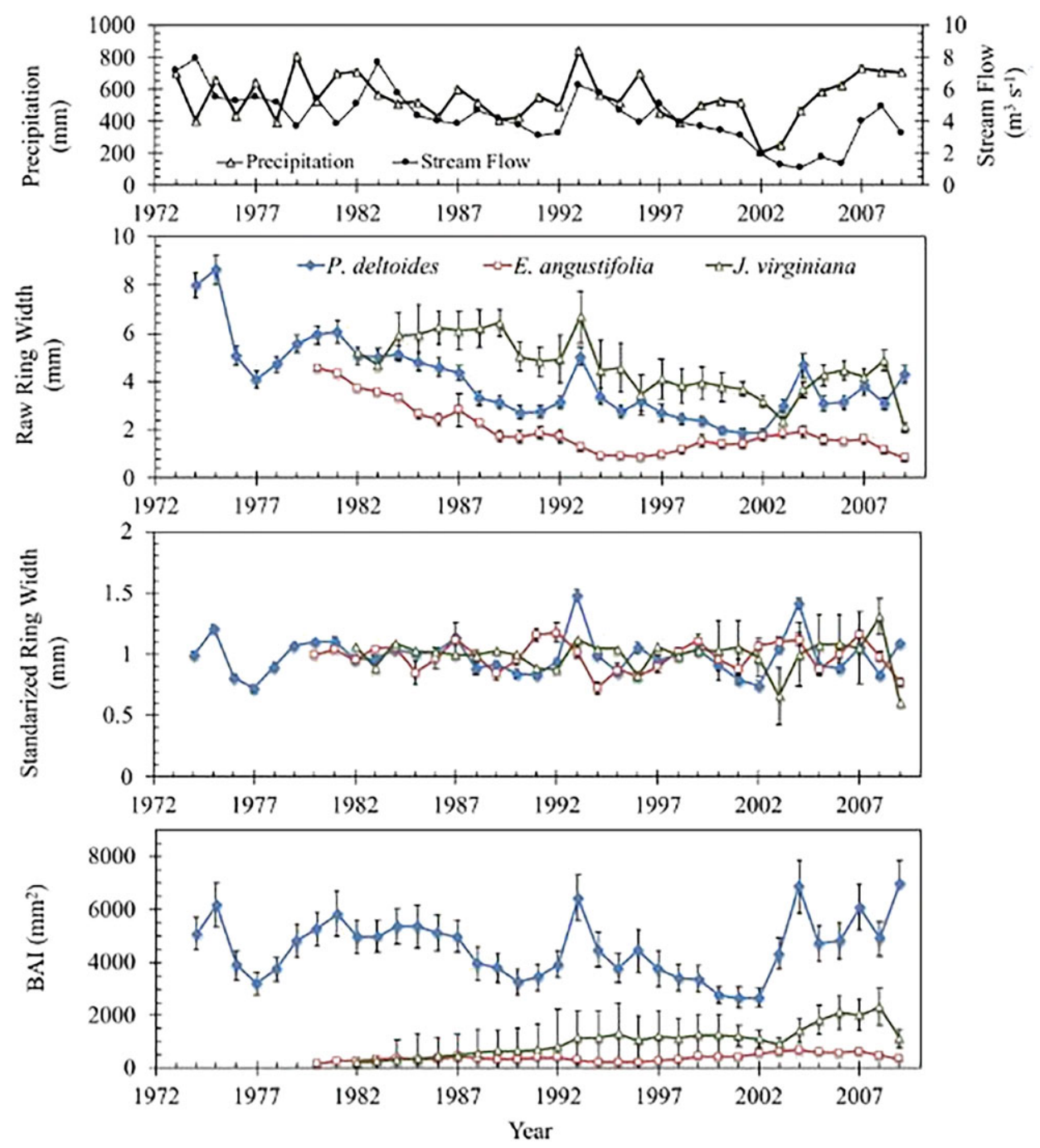

FIGURE 4 Annual precipitation and streamflow, average raw ring width, standardized ring width, and basal area increment tree ring chronologies with standard error bars for Populus deltoides (blue line), Juniperus virginiana (green line), and Elaeagnus angustifolia (red line)

results (Table 2) demonstrated that standardized ring widths are positively correlated with annual temperature and with previous year midseason average temperature. Standardized ring widths in P. deltoides are negatively correlated with minimum annual and previous September temperatures. Previous year, September temperature showed a significant negative correlation with standardized ring growth in J. virginiana, and average annual minimum temperatures exhibited a positive impact on E. angustifolia. Overall, the two invasive species did not seem to be as sensitive to temperature fluctuations as P. deltoides. 
TABLE 2 Effect of climate variables on raw ring width (Raw), standardized ring width, basal area increment, and carbon and oxygen isotope ratios $\left(\delta^{13} \mathrm{C}\right.$ and $\left.\delta^{18} \mathrm{O}\right)$

\begin{tabular}{|c|c|c|c|c|c|c|c|c|c|c|c|c|c|c|c|}
\hline \multirow[b]{2}{*}{ Climate Variable } & \multicolumn{5}{|c|}{ P. deltoides } & \multicolumn{5}{|c|}{ J. virginiana } & \multicolumn{5}{|c|}{ E. angustifolia } \\
\hline & Raw & STD & BAI & $\delta^{13} \mathrm{C}$ & $\overline{\delta^{18} \mathrm{O}}$ & Raw & STD & BAI & $\delta^{13} \mathrm{C}$ & $\overline{\delta^{18} \mathrm{O}}$ & Raw & STD & BAI & $\delta^{13} \mathrm{C}$ & $\delta^{18} \mathrm{O}$ \\
\hline \multicolumn{16}{|l|}{ GLM } \\
\hline Precipitation (GS) & & & & & & & $\sim$ & & & & & & & & $* * *$ \\
\hline Precipitation (PY) & & & & & $\sim$ & & & & & & & & & & $\sim$ \\
\hline Annual Min Temperature (PY) & $* *$ & * & & & & & & & & & & $* *$ & & & \\
\hline \multicolumn{16}{|l|}{ Correlations } \\
\hline \multicolumn{16}{|l|}{ Stream Flow } \\
\hline February-December (PY; per month) & * & * & & & & & & * & & & & & * & & \\
\hline February-August (PY; per month) & & & & & * & & & & & & * & & & & \\
\hline February (CY) & & & & & & * & & * & & & * & & * & & \\
\hline March (CY) & & & & & * & & & * & & & & * & * & & \\
\hline April (CY) & & & & & * & $\sim$ & * & $*$ & & & & & $*$ & & \\
\hline May (CY) & & & & & * & & & & & & & & & & \\
\hline June $(\mathrm{CY})$ & & & * & & & & & & & & & & * & & \\
\hline July (CY) & & & & & & * & & & & & * & & * & & \\
\hline August (CY) & & & & & & * & & * & & & * & * & * & & $*$ \\
\hline October (CY) & & & & & & * & * & * & & & & $*$ & * & & \\
\hline December (CY) & & * & & & & & $*$ & $*$ & & & * & $*$ & * & & \\
\hline August (PY) & & $* * *$ & $\sim$ & & & & & $* *$ & & & & & & & $* * *$ \\
\hline September (PY) & & & & & $\sim$ & & $* * *$ & & & $*$ & & & & & $* *$ \\
\hline October (PY) & * & & & & & & & & & & * & & & $\sim$ & $\sim$ \\
\hline November (PY) & * & & & & & & & & & & & & & & \\
\hline March (CY) & & & & & & & & & & & * & & & & \\
\hline October (CY) & & & & & & $*$ & & & & & & & & & \\
\hline \multicolumn{16}{|l|}{ Temperature } \\
\hline March (PY) & & & & & & & & & & & & & & & $*$ \\
\hline April (PY) & * & & & & * & & & & & & * & & & & \\
\hline May (PY) & & & & & * & & & & & * & $* *$ & & & $\sim$ & \\
\hline June (PY) & * & & & & $* * *$ & & & & * & & & & & & $* *$ \\
\hline July (PY) & & $* * *$ & $* * *$ & & $* * *$ & & & & $\sim$ & & $*$ & & $*$ & & $\sim$ \\
\hline August (PY) & & $* * *$ & & $\sim$ & $* * *$ & & & & & & & & & & \\
\hline September (PY) & & * & & & $* * *$ & & $* *$ & & & & & & & & $*$ \\
\hline October (PY) & * & & & & $* * *$ & & & & & & & & & & $\sim$ \\
\hline
\end{tabular}


TABLE 2 (Continued)

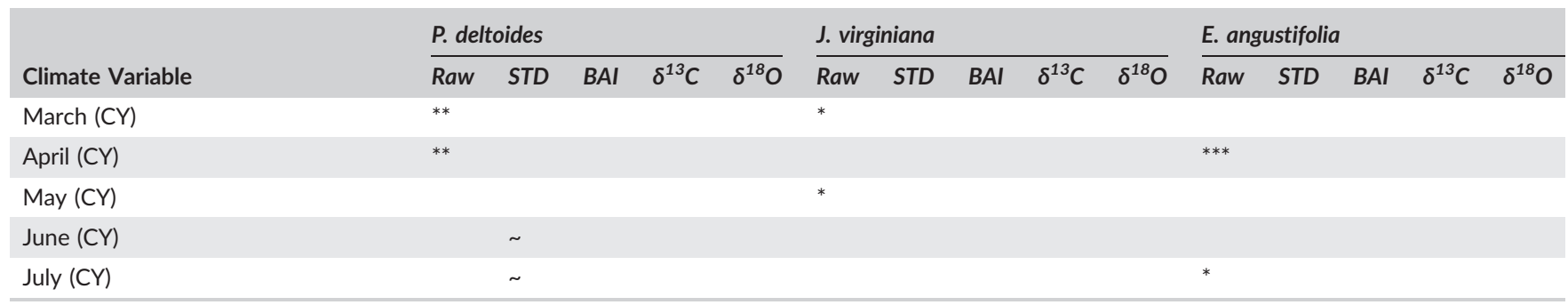

Note. Estimates are coded by their $p$-value significance with abbreviations: ${ }^{* * *}=p<0.001 ;{ }^{* *}=p<0.001 ;{ }^{*}=p<0.01 ; \sim=p<0.05$. AS: Annual Sum; CY: Current Year; GS: Growing Season; and PY: Previous Year. Responses were analysed as a function of current and previous year monthly, seasonal, and annual averages of climate variables. Only variables with significant responses are shown.

TABLE 3 Descriptive analysis of the chronologies used in this study with means and \pm standard error

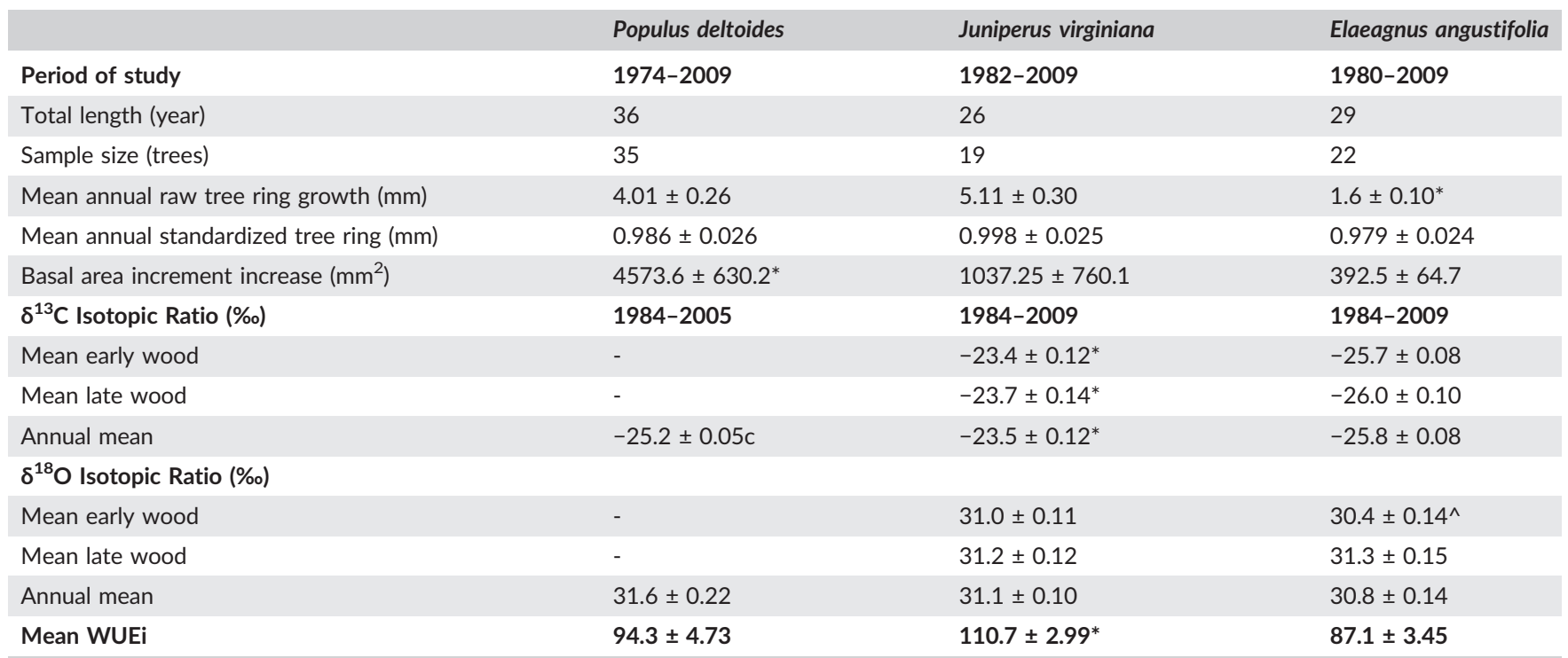

Note. It was not possible to isolate early wood from late wood in Populus deltoides. Asterisks $\left({ }^{*}\right)$ indicate significant differences between species at $p<0.05$. Carets $(\wedge)$ indicate differences between early and late wood of the same species at $p<0.05$.

\section{3 | Tree-ring isotopes and WUEi}

Oxygen isotope ratios $\left(\delta^{18} \mathrm{O}\right)$ followed a bimodal trend for all species during the period of study. The $\delta^{18} \mathrm{O}$ trends track precipitation and streamflow trends (Figure 5), which generally showed a negative relationship to $\delta^{18} \mathrm{O}$ (Table 2). $\delta^{18} \mathrm{O}$ declined in all species in 1992 and 1993, followed by an increase mirroring the observed drying trend, which peaked in 2002, a year of severe drought. The trend then declined steadily until the end of the study period in 2009. P. deltoides $\delta^{18} \mathrm{O}$ was more responsive to water availability and temperature relative to J. virginiana and E. angustifolia. We were not able to separate early from late wood in $P$. deltoides. However, our results for $J$. virginiana did not show any significant differences between early and late wood, and mean $\delta^{18} \mathrm{O}$ in late wood was significantly higher than early wood in E. angustifolia throughout the study (Table 3), except for 1993, 1996, and 2008 (data not shown, years with lowwater stress).
Even after accounting for $\delta^{13} \mathrm{C}$ in air (i.e., removal of fossil fuel effect), carbon isotope ratios $\left(\delta^{13} \mathrm{C}\right)$ increased over time, but this enrichment was only significant in $P$. deltoides and J. virginiana. This trend tended to reverse after 2002 with improvement in water conditions. The increase in $\delta^{13} \mathrm{C}$ in tree rings resulted in a significant increase in WUEi in all species over time and a decline in ci/ca (Figure 5). The coniferous $J$. virginiana had significantly higher $\delta^{13} \mathrm{C}$ and WUEi and lower $\mathrm{ci} /$ ca relative to deciduous $P$. deltoides and E. angustifolia (Figure 5, Table 2). Annual mean streamflow was negatively correlated with mean WUEi in all species (Figure 6) and with $\delta^{13} \mathrm{C}$ in J. virginiana and E. angustifolia and did not have any significant impact on $P$. deltoides. The latter was mostly impacted by previous year August temperature (Table 2). We also observed an increase in WUEi over time independent of streamflow, which is most likely associated with increased atmospheric $\mathrm{CO}_{2}$ concentrations. $\delta^{18} \mathrm{O}$ was also positively correlated with $\delta^{13} \mathrm{C}$ in the deciduous invasive $E$. angustifolia and native $P$. deltoides but not with native invasive J. virginiana (Figure 6). 
FIGURE 5 Average annual carbon and oxygen isotope ratios $\left(\delta^{13} \mathrm{C}\right.$ and $\delta^{18} \mathrm{O}$, respectively), intrinsic water use efficiency with standard error bars, and intercellular to air concentration of $\mathrm{CO}_{2}(\mathrm{Ci} / \mathrm{Ca})$ for Populus deltoides, Juniperus virginiana, and Elaeagnus angustifolia
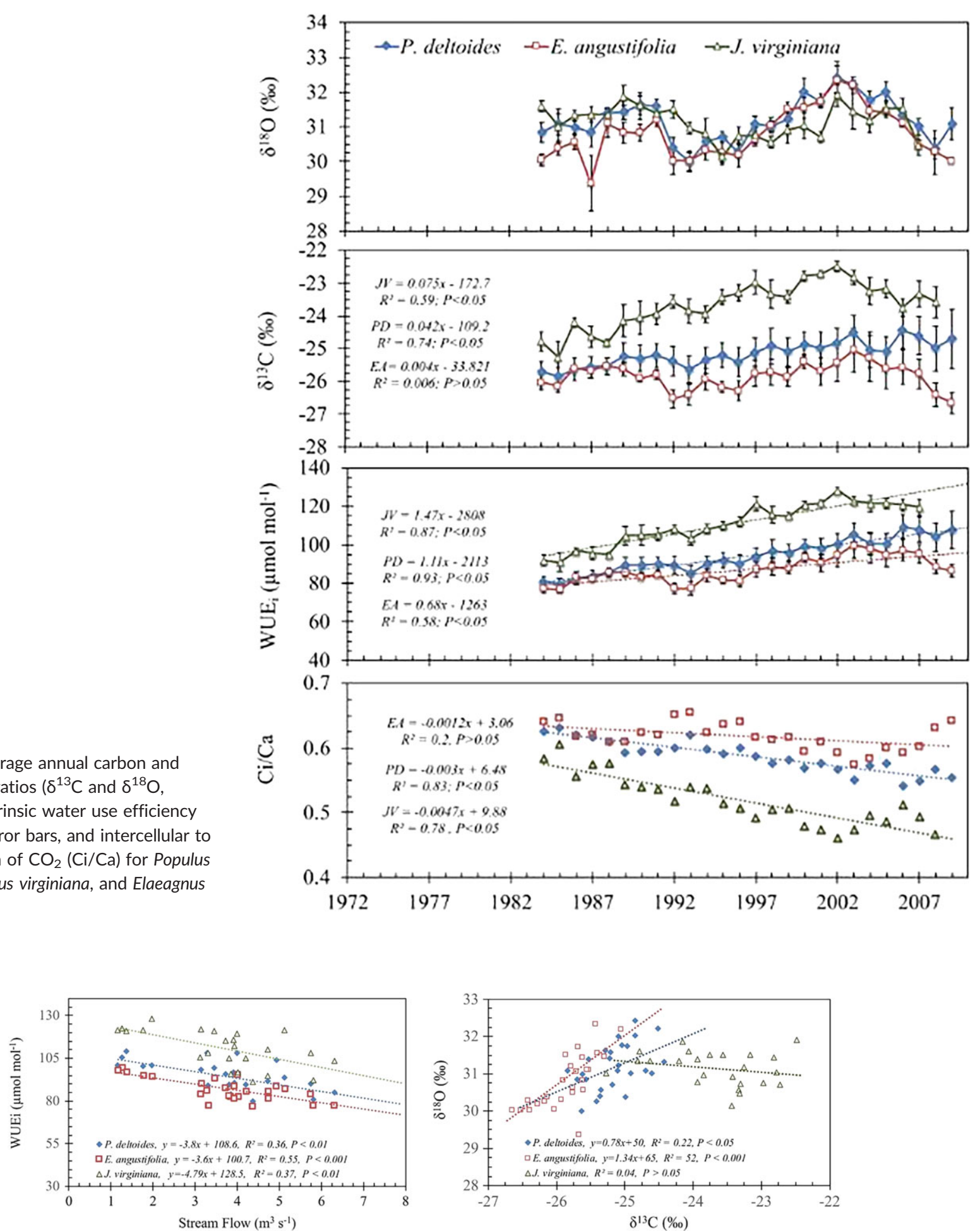

FIGURE 6 Intrinsic water use efficiency as a function of streamflow (left) and oxygen isotope ratio $\left(\delta^{18} \mathrm{O}\right)$ as a function of carbon isotope ratio $\left(\delta^{13} \mathrm{C}\right.$; right) for Populus deltoides, Juniperus virginiana, and Elaeagnus angustifolia

\section{4 | DISCUSSION}

Over the past century, riparian ecosystems across the United States have experienced drier conditions due to climatic fluctuation, streamflow regulation, vegetation cover change, agricultural practices, or a combination thereof (Huddle et al., 2011; Mykleby et al., 2016). The species examined in this study showed different responses to environmental variability. Growth of the native riparian $P$. deltoides, followed by the native aggressive upland J. virginiana, displayed more sensitivity to fluctuation in the abiotic environment compared with 
the invasive E. angustifolia. The most important predictor for growth was streamflow (Table 2, Figure 4), which, along with above-average precipitation and high PDI (extremely moist conditions), results in peak response in raw and standardized tree-ring growth in $P$. deltoides and J. virginiana but little response in E. angustifolia. However, a reduction in streamflow resulted in suppressed growth, even in years of aboveaverage precipitation (e.g., 1982), as indicated by measured ring parameters in $P$. deltoides and raw ring growth of $J$. virginiana. Decline in streamflow and water table have been shown to have adverse effects on Populus sp. (Lovell et al., 2009), as manifested by changes and reductions in sap flow and sap area and narrower tree rings (Lambs et al., 2006; Muller \& Lambs, 2009).

Phreatophyte riparian trees that rely on groundwater, such as in semiarid areas of the Great Plains, are considered to be more susceptible to water table and streamflow fluctuations (Huddle et al., 2011; Scott, Shuttleworth, Goodrich, \& Maddock, 2000; Stromberg, Beauchamp, Dixon, Lite, \& Paradzick, 2007) than invasive woody species like J. virginiana and E. angustifolia. Such woody species possess higher root plasticity and a greater ability to use multiple water sources in the soil profile, including the groundwater and the unsaturated soil profile (e.g., Awada et al., 2013; Eggemeyer et al., 2009; Snyder \& Williams, 2000; Zhang et al., 2016). We did not record any statistically significant differences in $\delta^{18} \mathrm{O}$ values among the species, which indicates that all three species were utilizing similar water sources and apparently had similar stomatal conductances. This supports the findings that some riparian phreatophytes can utilize more growing season precipitation, which recharges soil water in areas where a substantial proportion of annual precipitation occurs during the growing season (Chimner \& Cooper, 2004). Increases in winter minimum average temperatures were negatively correlated with standardized ring growth in $P$. deltoides. This warming trend during winter months can cause thawing followed by a re-freezing of the roots when temperatures drop, leading to tree damage and even crown dieback in deciduous shallow-rooted species (Pomerleau, 1991). On the other hand, warming summer temperatures can increase transpiration and respiration and are often associated with higher radiation and drought potential, impacting net assimilation rates and growth. In comparison with $P$. deltoides and J. virginiana, E. angustifolia showed the least significant correlations between growth and climate variables. Previous studies have found that $E$. angustifolia is capable of growing in areas with a high-minimum temperature and low-pulse floods (Reynolds \& Cooper, 2010). Compared with other invasive species such as Tamarix sp., E. angustifolia seems to be less sensitive to disturbances in the ecosystem and is able to grow in densely shaded areas above the typical floodplain of a river (Mortenson \& Weisberg, 2010). These traits contribute to the success of $E$. angustifolia invasion in riparian areas. Similarly, a tree-ring study of the performance of upland J. virginiana along a precipitation gradient across Nebraska showed that the establishment and growth of the species was not limited by climate and water availability in the eastern part of the state (average annual precipitation of $850 \mathrm{~mm}$ ). Both displayed a lower interannual variability in tree-rings during the first years of establishment relative to individuals towards the western end of the gradient (average annual precipitation of $570 \mathrm{~mm}$ ), which were more dependent on water availability (Aus der Au et al., 2018).

\subsection{Carbon and oxygen stable isotope ratios}

The combined analyses of $\delta^{13} \mathrm{C}$ and $\delta^{18} \mathrm{O}$ in tree rings provide a means to investigate long-term ecophysiological strategies associated with microclimate fluctuations and extremes (Liu et al., 2014; Scheidegger, Saurer, Bahn, \& Siegwolf, 2000; Sullivan, Pattison, Brownlee, Cahoon, \& Hollingsworth, 2017). Specifically, ci and WUEi can be estimated from $\delta^{13} \mathrm{C}$ in organic tissues due to the linear relationship between $\mathrm{ci} / \mathrm{ca}$ and $\delta^{13} \mathrm{C}$ (Farquhar et al., 1982). Relative humidity (RH) and water sources can be estimated from $\delta^{18} \mathrm{O}$, with the assumption that vapour pressure in the intercellular space is an important parameter that affects stomatal conductance $\left(\mathrm{g}_{\mathrm{s}}\right)$. Therefore, the combination of $\delta^{13} \mathrm{C}$ and $\delta^{18} \mathrm{O}$ analyses can address the question of whether the $\mathrm{CO}_{2}$ assimilation rate is more strongly impacted by stomatal or carboxylation constraints, thus providing insights into the relationship between $\mathrm{g}_{\mathrm{s}}$ and photosynthetic capacity (Lévesque, Siegwolf, Saurer, Eilman, \& Rigling, 2014). For instance, a reduction in ci and an increase in $\delta^{13} \mathrm{C}$ can be interpreted either as a reduction in $\mathrm{g}_{\mathrm{s}}$ or an increase in the $\mathrm{CO}_{2}$ assimilation rate at a constant $\mathrm{g}_{\mathrm{s}}$ (Scheidegger et al., 2000). On the other hand, $\delta^{18} \mathrm{O}$ reflects the meteoric source of water, transpirational demands, and biochemical fractionations during organic matter formation (Battipaglia et al., 2013). Its enrichment increases with vapour pressure deficit and decreases with $\mathrm{RH}$ (Battipaglia et al., 2013; Saurer, Aellen, \& Siegwolf, 1997; Tene et al., 2011). Both isotopes, therefore, indicate changes in $g_{s}$ at the leaf level associated with soil moisture variability and evaporative demands. In this study, the $\delta^{13} \mathrm{C}$ ratio was consistently higher in J. virginiana than in P. deltoides and E. angustifolia (Figure 5). This indicates a higher WUEi in J. virginiana relative to the other examined species, which is a result of either lower stomatal conductance or higher rates of photosynthesis (Eilmann et al., 2010; Saurer et al., 1997; Tene et al., 2011). The $\delta^{18} \mathrm{O}$ ratio followed a similar trend in all species, demonstrating a strong tissue enrichment during periods of lower water availability due to declines in $g_{s}$ and possibly access to a more enriched source of water from the unsaturated soil profile in all species, including the native $P$. deltoides. This finding supports the hypothesis that some riparian phreatophytes can utilize growing season precipitation, which recharges soil water (Chimner \& Cooper, 2004). However, when these two isotopes are considered together with ci/ca values (Figures 5 and 6), a change in $\delta^{13} \mathrm{C}$ in J. viginiana was not associated with significant changes in $\delta^{18} \mathrm{O}$. This suggests that $J$. virginiana exhibits less stomatal control, conductance, and lower sensitivity to $\mathrm{RH}$ than either $P$. deltoides or E. angustifolia and thus uses a different drought resistance strategy. Other studies have found that J. virginiana shows a clear anisohydric behavior that allows the species to function under a wider range of water potentials (Eggemeyer, Awada, Wedin, Harvey, \& Zhou, 2006; Eggemeyer et al., 2009; Wilson, Manos, \& Jackson, 2008, Volder, Tjoelker, \& Briske, 2010, Awada et al., 2013) than isohydric species, which exhibit strong stomatal control and keep 
water potential above a threshold to avoid cavitation (e.g. McDowell et al., 2008). A strong isohydric stomatal behaviour was observed in $P$. deltoides and to a lesser extent in E. angustifolia. Both species displayed a lower WUEi and a significant positive relationship between $\delta^{18} \mathrm{O}$ and $\delta^{13} \mathrm{C}$ (Liu et al., 2014). The relationship between $\delta^{18} \mathrm{O}$ and $\delta^{13} \mathrm{C}$ in $\mathrm{P}$. deltoides and $\mathrm{E}$. angustifolia was significant, indicating the important role of $\mathrm{g}_{\mathrm{s}}$ in regulating photosynthesis. Although significant, the relationship between $\delta^{18} \mathrm{O}$ and $\delta^{13} \mathrm{C}$ for $\mathrm{E}$. angustifolia varied more, indicating that this species is limited by other internal factors. This is demonstrated by an increase in ci/ca during years with higher stomatal conductance, which shows that in this case, it is very likely that photosynthesis was limited by maximum carboxylation capacity in E. angustifolia (Scheidegger et al., 2000). This is further evidenced by the constant annual growth of this species irrespective of the abiotic environment, which can explain in part its success along the Republican River and elsewhere. Traditionally, E. angustifolia has been observed to thrive in wet meadows, underneath forest canopies, and in riparian forests (Reynolds \& Cooper, 2010). Because they are able to grow in densely shaded areas above the typical flood plain of a river, E. angustifolia seedlings prove much more resistant than similarly aged native riparian trees (Mortenson \& Weisberg, 2010; Reynolds \& Cooper, 2010). The correlations between current year $\delta^{18} \mathrm{O}$ and $\delta^{13} \mathrm{C}$ with current and previous year climatic variables indicate that although most of the growth in current year rings is associated with current season conditions, there is also some dependency on previous year conditions. This demonstrates that previous year carbohydrates contribute to current year tree-ring development (Zhang et al., 2016).

\section{5 | CONCLUSIONS}

Surface and ground water levels along riparian systems in the semiarid Great Plains vary significantly across years and can be exacerbated by drought, water human use, water flow regulation, and riparian vegetation water use. This fluctuation affects riparian vegetation, often at the expense of historically native species (Mortenson \& Weisberg, 2010; Mykleby et al., 2016; Richardson et al., 2007; Rood et al., 2007), as we have demonstrated. Our results show that streamflow and water availability are important predictors of $P$. deltoides tree growth and to a lesser extent of J. virginiana growth. E. angustifolia was the least affected by the environmental fluctuations reported during the study period (1973-2009). These results have significant consequences for improving our understanding of ecological processes along the Republican River and elsewhere. Altered ecohydrological processes have been shown to change riparian community composition, structure, and function and, in many cases, facilitate the encroachment of native nonriparian or invasive alien species, further impacting the ecohydrology and surface water availability in the system. Flood control in these areas have further exacerbated the problem by suppressing the regeneration of $P$. deltoides, which relies on overbank flooding for germination and establishment. Conversely, the lack of flooding facilitates the spread of J. virginiana and
E. angustifolia by allowing these flood-adverse species to become established. These two species have been widely planted across the Great Plains since the 1900 s and are known to produce large numbers of seeds that spread and germinate under a range of environmental conditions (Ganguli, Engle, Mayer, \& Hellgren, 2008; Huddle et al., 2011 and references therein). Once established, J. Virginiana and $E$. angustifolia thrive in the understory of $P$. deltoides. Current management practices and adaptation to local climate promote the continuous establishment and spread of these two species throughout the Republican River watershed and elsewhere, with significant impacts on ecosystem services and resilience.

\section{ACKNOWLEDGEMENTS}

This study was supported by the McIntire Stennis Forestry Research Fund (USDA) and by the Nebraska Department of Natural Resources. Kristen Skolaut would like to thank LiCor Inc. for supporting her MS studies at the University of Nebraska-Lincoln. We thank Magdalena Nötzli for assisting with tree coring and sample processing at the WSL.

\section{ORCID}

Paolo Cherubini (D) https://orcid.org/0000-0002-9809-250X

\section{REFERENCES}

Akaike, H. (1973). Information theory as an extension of the maximum likelihood principle. In B. N. Petrov, \& F. Csaki (Eds.), Second international symposium on information theory (pp. 267-281). Budapest: Akademiai Kiado.

Aus der Au, R., Awada, T., Hiller, G., Battipaglia, G., Saurer, M., \& Cherubini, P. (2018). Tree rings of Pinus ponderosa and Juniperus virginiana show different responses to stand density and water availability in the Nebraska grasslands. American Midland Naturalist, 180, 18-36.

Awada, T., El-Hage, R., Geha, M., Wedin, D. A., Huddle, J. A., Zhou, X., ... Brandle, J. R. (2013). Intra-annual variability and environmental controls over transpiration in a 58-year-old even-aged stand of invasive woody Juniperus virginiana L. in the Nebraska Sandhills, USA. Ecohydrology, 6, 731-740.

Battipaglia, G., Saurer, M., Cherubini, P., Calfapietra, C., McCarthy, H. R., Norb, R. J., \& Francesca Cotrufo, M. (2013). Elevated $\mathrm{CO}_{2}$ increases tree-level intrinsic water use efficiency: Insights from carbon and oxygen isotope analyses in tree rings across three forest FACE sites. New Phytologist, 197, 544-554. https://doi.org/10.1111/nph.12044

Biondi, F., \& Waikul, K. (2004). DENDROCLIM2002: A C++ program for statistical calibration of climate signals in tree-ring chronologies. Computers and Geosciences, 30, 303-311. https://doi.org/10.1016/j. cageo.2003.11.004

Burnham, K. P., \& Anderson, D. R. (2002). Model selection and multimodel inference: A practical information-theoretical approach (2nd ed.). New York: Springer-Verlag.

Cherubini, P., Fontana, G., Rigling, D., Dobbertin, M., Brang, P., \& Innes, J. L. (2002). Tree-life history prior to death: Two fungal root pathogens affect tree-ring growth differently. Journal of Ecology, 90, 839-850. https://doi.org/10.1046/j.1365-2745.2002.00715.x

Chimner, R. A., \& Cooper, D. J. (2004). Using stable oxygen isotopes to quantify the water source used for transpiration by native shrubs in the San Luis Valley, Colorado U.S.A. Plant and Soil, 260, 225-236. 
Cleverly J.R., Dahm C.N., Thibault J.R., McDonnell D.E., and Coonrod J. E.A. (2006). Riparian ecohydrology: Regulation of water flux from the ground to the atmosphere in the Middle Rio Grande, New Mexico. Hydrological Processes, 20:3207-3225

Cleverly, R., Dahm, C. N., Thibault, J. R., McDonnell, D. E., \& Coonrod, J. E. A. (2006). Riparian ecohydrology: Regulation of water flux from the ground to the atmosphere in the Middle Rio Grande, New Mexico. Hydrological Processes, 20, 3207-3225. https://doi.org/10.1002/ hyp.6328

Conte, E., Lombardi, F., Battipaglia, G., Palombo, C., Altieri, S., La PortaN., ... Tognetti, R. (2018). Growth dynamics, climate sensitivity and water use efficiency in pure vs. mixed pine and beech stands in Trentino (Italy). Forest Ecology and Management, 409, 707-718.

Cook E.R., and Holmes R.L. (1986). Users manual for program ARSTAN. Laboratory of Tree-Ring Research, University of Arizona, Tuscon.

Eggemeyer, K., Awada, T., Harvey, F. E., Wedin, D., Zhou, X., \& Zanner, C. W. (2009). Seasonal changes in depth of water uptake for encroaching trees Juniperus virginiana and Pinus ponderosa and two dominant $C_{4}$ grasses in a semiarid grassland. Tree Physiology, 29, 157-169. https:// doi.org/10.1093/treephys/tpn019

Eggemeyer, K., Awada, T., Wedin, D., Harvey, F. E., \& Zhou, X. (2006). Ecophysiology of two native invasive woody species and two dominant warm-season grasses in the semiarid grasslands of the Nebraska Sandhills. International Journal of Plant Sciences, 167, 991-999. https://doi.org/10.1086/505797

Eilmann, B., Buchmann, N., Siegwolf, R., Saurer, M., Cherubini, P., \& Rigling, A. (2010). Fast response of Scots pine to improved water availability reflected in tree-ring width and $\delta^{13} \mathrm{C}$. Plant, Cell and Environment, 33, 1351-1360.

Farquhar, G. D., O'Leary, M. H., \& Berry, J. A. (1982). On the relationship between carbon isotope discrimination and the intercellular carbon dioxide concentration in leaves. Australian Journal of Plant Physiology, 9, 121-137.

Fritts, H. C. (1966). Growth-rings of trees: Their correlation with climate. Science, 154, 973-979. https://doi.org/10.1126/science.154. 3752.973

Ganguli, A., Engle, D., Mayer, P., \& Hellgren, E. (2008). Plant community diversity and composition provide little resistance to Juniperus encroachment. Botany, 86, 1416-1426. https://doi.org/10.1139/ B08-110

Green, J. W. (1963). Wood cellulose. Methods in Carbohydrate Chemistry, 3, 9-21.

Grissino-Mayer H.D., Holmes R.L., and Fritts H.C. (1996). The International Tree Ring Data Bank Program Library Version 2.0 User's Manual. Laboratory of Tree Ring Research, University of Arizona, Tucson, USA.

Heilman, J. L., McInnes, K. J., Kjelgaard, J. F., Owens, M. K., \& Schwinning, S. (2009). Energy balance and water use in a subtropical karst woodland on the Edwards Plateau, Texas. Journal of Hydrology, 373, 426-435. https://doi.org/10.1016/j.jhydrol.2009.05.007

Huddle, J., Awada, T., Martin, D., Zhou, X., Pegg, S. E., \& Josiah, S. (2011). Do invasive riparian woody plants affect hydrology and ecosystem processes? Great Plains Research, 21, 49-71.

Lambs, L., Loubiat, M., Girel, J., Tissier, J., Peltier, J. P., \& Marigo, G. (2006). Survival and adaptation of Populus nigra to drier conditions after damming of an alpine river, southeast France. Annals of Forest Science, 63, 377-385. https://doi.org/10.1051/forest:2006018

Lévesque, M., Siegwolf, R., Saurer, M., Eilman, B., \& Rigling, A. (2014). Increased water use efficiency does not lead to enhanced tree growth under xeric and mesic conditions. New Phytologist, 203, 94-109. https://doi.org/10.1111/nph.12772
Littell, R. C., Milliken, G. A., Stroup, W. W., Wolfinger, R. D., \& Schabenberger, O. (2006). SAS ${ }^{\circ}$ for mixed models (Second ed.). North Carolina, USA: SAS Institute Inc. Cary.

Liu, X., Wang, W., Xu, G., Zeng, X., Wu, G., Zhang, X., \& Qin, D. (2014). Tree growth and intrinsic water-use efficiency of inland riparian forests in north-western China: evaluation via $\delta^{13} \mathrm{C}$ and $\delta^{18} \mathrm{O}$ analysis of tree rings. Tree Physiology, 34, 966-980. https://doi.org/10.1093/ treephys/tpu067

Lovell, J., Gibson, J., \& Heschel, M. S. (2009). Disturbance regime mediates riparian forest dynamics and physiological performance, Arkansas River, CO. The American Midland Naturalist, 162, 289-304. https:// doi.org/10.1674/0003-0031-162.2.289

Margolis, E., Meko, D., \& Touchan, R. (2011). A tree-ring reconstruction of streamflow in the Santa Fe River, New Mexico. Journal of Hydrology, 397, 118-127. https://doi.org/10.1016/j.jhydrol.2010.11.042

McCarroll, D., \& Loader, N. J. (2004). Stable isotopes in tree rings. Quaternary Science Reviews, 23, 7-8.

McDowell, N., Pockman, W. T., Allen, C. D., Breshears, D. D., Cobb, N., Kolb, T., ... Yepez, E. A. (2008). Mechanisms of plant survival and mortality during drought: Why do some plants survive while others succumb to drought? New Phytologist, 178, 719-739. https://doi.org/ 10.1111/j.1469-8137.2008.02436.x

Mortenson, S., \& Weisberg, P. (2010). Does river regulation increase the dominance of invasive woody species in riparian landscapes? Global Ecology and Biogeography, 19, 562-574.

Msanne, J., Awada, T., Bryan, N. M., Schacht, W., Drijber, R., Li, Y., ... Hiller, J. (2017). Ecophysiological responses of native invasive woody Juniperus virginiana $\mathrm{L}$. to resource availability and stand characteristics in the semi-arid grasslands of the Nebraska Sandhills. Photosynthetica, 55, 219-230. https://doi.org/10.1007/s11099-016-0683-y

Muller, E., \& Lambs, L. (2009). Daily variations of water use with vapor pressure deficit in a plantation of 1214 poplars. Water, 1, 32-42. https://doi.org/10.3390/w1010032

Mykleby, P. M., Lenters, J. D., Cutrell, G. J., Herrman, K. S., Istanbulluoglu, E., Scott, D. T., ... Dong, B. (2016). Energy and water response of a vegetated wetland to herbicide treatment of invasive Phragmites australis. Journal of Hydrology, 539, 290-303. https://doi.org/10.1016/j. jhydrol.2016.05.015

Naiman, R. J., \& Décamps, H. (1997). The ecology of interfaces: Riparian Zones. Annual Review of Ecology and Systematics, 28, 621-665. https://doi.org/10.1146/annurev.ecolsys.28.1.621

Núñez, D., Nahuelhual, L., \& Oyarzún, C. (2006). Forests and water: The value of native temperate forests in supplying water for human consumption. Ecological Economics, 58, 606-616. https://doi.org/ 10.1016/j.ecolecon.2005.08.010

Odum, E. P. (1971). Fundamentals of ecology (p. 574). Philadelphia, PA: Saunders.

Pinheiro, J., Bates, D., DebRoy, S., \& Sarkar, D. (2009). R Core Team, Linear and nonlinear mixed effects models. $R$ Package Version, 3, 1-96.

Pomerleau R. (1991). Experiments on the causal mechanisms of dieback on deciduous forests in Québec. Québec Region Canadian Forest Service, Information Report LAU-X-96, 47.

R Development Core Team, 2009. $R$ : A language and environment for statistical computing. R Foundation for Statistical Computing, Vienna. Available from URL: http://www.rproject. org/foundation.

Rahel, F. J., \& Olden, J. D. (2008). Assessing the effects of climate change on aquatic invasive species. Conservation Biology, 22, 521-533. https:// doi.org/10.1111/j.1523-1739.2008.00950.x

Reynolds, L., \& Cooper, D. (2010). Environmental tolerance of an invasive riparian tree and its potential for continued spread in the southwestern US. Journal of Vegetation Science, 21, 733-743. 
Richardson, D. M., Holmes, P. M., Esler, K. J., Galatowitsch, S. M., Stromberg, J. C., Kirkman, S. P., ... Hobbs, R. J. (2007). Riparian vegetation: degradation, alien plant invasions, and restoration projects. Diversity and Distributions, 13, 126-139. https://doi.org/10.1111/ j.1366-9516.2006.00314.x

Rood, S. B., Braatne, J. H., \& Hughes, F. M. R. (2003). Ecophysiology of riparian cottonwoods: stream flow dependency, water relations and restoration. Tree Physiology, 23, 1113-1124. https://doi.org/10.1093/ treephys/23.16.1113

Rood, S. B., Goater, L., Mahoney, J., Pearce, C., \& Smith, D. (2007). Floods, fire, and ice: disturbance ecology of riparian cottonwoods. Canadian Journal of Botany, 85, 1019-1032. https://doi.org/10.1139/B07-073

Saurer, M., Aellen, K., \& Siegwolf, R. (1997). Correlating $\delta^{13} \mathrm{C}$ and $\delta^{18} \mathrm{O}$ in cellulose of trees. Plant, Cell and Environment, 20, 1543-1550. https://doi.org/10.1046/j.1365-3040.1997.d01-53.x

Scheidegger, Y., Saurer, M., Bahn, M., \& Siegwolf, R. (2000). Linking stable oxygen and carbon isotopes with stomatal conductance and photosynthetic capacity: A conceptual model. Oecologia, 125, 350-357. https:// doi.org/10.1007/s004420000466

Scott, R. L., Shuttleworth, W. J., Goodrich, D. C., \& Maddock, T. III (2000). The water use of two dominant vegetation communities in a semiarid riparian ecosystem. Agricultural and Forest Meteorology, 105, 241-256. https://doi.org/10.1016/S0168-1923(00)00181-7

Singer, M. B., Stella, J. C., Dufour, S., Piégay, H., Wilson, R. J. S., \& Jhonstone, L. (2013). Contrasting water-uptake and growth responses to drought in co-occurring riparian tree species. Ecohydrology, 6, 402-412. https://doi.org/10.1002/eco.1283

Snyder, K., \& Williams, D. (2000). Water sources used by riparian trees varies among stream types on the San Pedro River, Arizona. Agricultural and Forest Meteorology, 105, 227-240. https://doi.org/10.1016/ S0168-1923(00)00193-3

Stromberg, J. C., Beauchamp, V. B., Dixon, M. D., Lite, S. J., \& Paradzick, C. (2007). Importance of low-flow and high-flow characteristics to restoration of riparian vegetation along rivers in arid south-western United States. Freshwater Biology, 52, 651-679. https://doi.org/10.1111/ j.1365-2427.2006.01713.x

Stromberg, J. C., Tiller, R., \& Richter, B. (1996). Effects of groundwater decline on riparian vegetation of semi-arid regions: The San Pedro, Arizona. Ecological Applications, 6, 113-131. https://doi.org/10.2307/ 2269558

Sullivan, P. F., Pattison, R. R., Brownlee, A. H., Cahoon, S. M., \& Hollingsworth, T. N. (2017). Limited evidence of declining growth among moisture limited black and white spruce in interior Alaska.
Scientific Reports, 7, 15344. https://doi.org/10.1038/s41598-01715644-7

Sun, S., Zhou, G., Zhang, Z., Wei, X., McNulty, S. G., \& Vose, J. M. (2006). Potential water yield reduction due to forestation across China. Journal of Hydrology, 328, 548-558. https://doi.org/10.1016/j.jhydrol. 2005.12.013

Tabacchi, E., Lambs, L., Guilloy, H., Planty-Tabacchi, A. M., Muller, E., \& Décamps, H. (2000). Impacts of riparian vegetation on hydrological processes. Hydrological Processes, 14, 2959-2967. https://doi.org/ 10.1002/1099-1085(200011/12)14:16/17<2959::AID-HYP129>3.0. CO;2-B

Tene, A., Tobin, B., Dyckmans, J., Ray, D., Black, K., \& Nieuwenhuis, M. (2011). Assessment of tree response to drought: Validation of a methodology to identify and test proxies for monitoring past environmental changes in trees. Tree Physiology, 31, 309-322. https://doi.org/ 10.1093/treephys/tpq114

Valor, T., Casals, P., Altieri, S., González-Olabarria, J. R., Piqué, M., \& Battipaglia, G. (2018). Disentangling the effects of crown scorch and competition release on the physiological and growth response of Pinus halepensis Mill. using $\delta 13 \mathrm{C}$ and $\delta 180$ isotopes. Forest Ecology and Management, 424, 276-287.

Volder, A., Tjoelker, M., \& Briske, D. (2010). Contrasting physiological responsiveness of establishing trees and a $\mathrm{C}_{4}$ grass to rainfall events, intensified summer drought, and warming in oak savanna. Global Change Biology, 16, 3349-3362. https://doi.org/10.1111/j.13652486.2009.02152.x

Wilson, C. J., Manos, P. S., \& Jackson, R. B. (2008). Hydraulic traits are influenced by phylogenetic history in the drought-resistant, invasive genus Juniperus (Cupressaceae). American Journal of Botany, 95, 299-314. https://doi.org/10.3732/ajb.95.3.299

Zhang, J., Gou, X., Zhang, Y., Lu, M., Xu, X., Zhang, F., ... Gao, L. (2016). Forward modeling analysis of Qilian juniper (Sabina przewalskii) of the Qilian mountains, northwestern China. Trees, 30, 175-188. https:// doi.org/10.1007/s00468-015-1286-0

How to cite this article: Awada T, Skolaut K, Battipaglia G, et al. Tree-ring stable isotopes show different ecophysiological strategies in native and invasive woody species of a semiarid riparian ecosystem in the Great Plains of the United States. Ecohydrology. 2019;12:e2074. https://doi.org/10.1002/eco.2074 